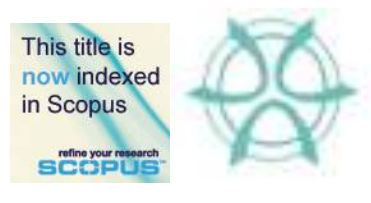

PLANNING MALAYSIA:

Journal of the Malaysian Institute of Planners

SPECIAL ISSUE IV (2016), Page 109 - 120

\title{
INFLUENCES OF HOUSING SETTINGS AND DESIGNS IN FULFILLING THE MALAY RESIDENTS' SOCIAL CULTURES
}

\author{
Noor Aimran Samsudin ${ }^{1} \&$ Syed Zainol Abidin Idid ${ }^{2}$ \\ ${ }^{1,2}$ Faculty of Built Environment \\ UNIVERSITI TEKNOLOGI MALAYSIA
}

\begin{abstract}
This study discusses on the influence of settlement settings and an ideal housing design that can shape a good society and excel in behaviour, the value of life and lifestyle daily. Living environment affects its inhabitants, including the opportunity for the Malay community to practice their norm and values based on Islamic teachings. There are two housing categories in Malaysia, namely as an unplanned settlement (kampongs) and planned settlement (urban housing). Nowadays, majority of the Urban-Malay community are living in modern housing estates in urban areas where the living sphere is different from a traditional settlement such as kampong in rural area. The living environment setting such as the kampongs encourage Malay residents to practice their social cultures. The Malay socio-cultural aspect is established slowly and evolves through time based on values required by religion and inherited from one generation to another. Malays have to comply with all the teachings and practice the values required by Islam. This paper suggests that, to meet such Malay residents' need, a certain physical design attributes from the kampongs should be applied in the modern housing environment at two different levels, called as the micro (house unit) and macro (settlement or neighbourhood) level. Based on the various literature sources, the requirement of optimum living space, the social activities, the family relationship, the neighbourhood concepts and preservation of the privacy element within Malay settlement have been discussed. As a comparison, the existing of linked housing setting has been reviewed in order to compare between the modern and traditional living environments. This paper proposed that the Muslim-Malay resident social cultures are a basis of Malay lifestyle and should be taken into account during the design of a settlement as a whole living environment setting.
\end{abstract}

Keyword: Housing design and settings, Social-cultures, Linked-house, Kampongs

\section{INTRODUCTION}

In the current housing market, there are various types of houses offered for sale by the developer to the buyer. Residential development in Malaysia is operated either by the government through the relevant agencies or private sectors. Housing is a basic necessity for all walks of life. Based on the Preliminary Count Report, Population and Housing Census of Malaysia in 2010 there are 7,380,865 units of 'living quarters'. Living quarters are a place which is structurally separated and independent and is meant for living (Department of Statistics Malaysia, 2010). The term 'separate' means a structure 
Noor Aimran Samsudin \& Syed Zainol Abidin Idid

Influences of Housing Settings and Designs in Fulfilling the Malay Residents' Social Cultures

surrounded by walls, fences and covered by a roof. While the term 'independent' means any unit has direct access via stairs, roads, and open-space without passing through the other people's territory. Generally, the 'rumah' word in Malay is a reference to any building that is used for shelter and living place (Dewan Bahasa dan Pustaka, 2015). Various policies and strategies were formulated and implemented to help improve the ability of property ownership, especially home ownership among the community. In addition to ensuring basic direction in the planning and development of the housing sector by various stakeholders, a policy, the National Housing Policy (NHP), was introduced. The main objective of the NHP is to provide adequate, comfortable, affordable housing to enhance the quality of life and sustainability (National Housing Policy, 2011).

The question is whether the diversity in the design of housing units offered in the existing market takes into account the needs of Muslim buyers to live in compliance with the teachings and values of Islam in their daily lives? The question is subjective and difficult to measure because there is no specific guideline to build a residential area that complies with the requirements of Muslim life. But Islam outlines some general principles regarding good residential quality like good quality and comfortable home, upholding the good virtue of the local neighbourhood, choosing good neighbours, protecting the environment, maintaining individual privacy, up keeping personal and family safety and protecting individual property. Yusoff et.al. (2004) quoted a 'hadith' narrated by Al-Thabrani in which the Messenger of Allah said:

"There are three achievements of a Muslim in the world, one of which has a spacious and comfortable home".

While another 'hadith' narrated by Ibn Hibban means:

"The Prophet (peace and blessings be upon him) said, meaning: Four things can cause happiness. A pious wife, a spacious house, a good neighbour and a comfortable transport!"

The house is also not limited to the function as a residence that provides spaces to do activities such as eating, sleeping, rest and so on, but also as a place of worship by members. Narrated by al-Bukhary and Muslim, the Prophet said:

"Oh people! Perform your (voluntary) solat (prayers) in your homes because the best solat of a man is the one he performs at home except the obligatory solat."

\section{OBJECTIVES}

The purpose of this paper is to discuss the need for a more comprehensive study on the extent of detailed design of the house and its environment that can encourage the Malay community to meet the values of Islam. This study focuses on potential conflicts in modern residential area of linked houses. By comparison, the layout of traditional houses in the village and the environment were also discussed. To what extent the traditional house design and its surrounding setting can meet the aspirations of its inhabitants compared to a more modern housing in the current market? The issues are important to 
be discussed because the environment where people live in influences human behaviour. Indirectly, the environments where humans reside affect their character, personalities, and values. This paper suggests that an ideal place to stay should be able to provide an opportunity for residents to meet the values of Islam.

\section{PROBLEM AND ISSUES}

A question arises here whether the social problems in the society today is attributed to the failure of the design of living environment? The question is in line with the question why the social problems among the Malay community who are generally Muslims are severe and upsetting while Islam is the religion of the community? What kind of people will be the product of the environment we designed if the theories of environmental determinism on human behaviour really exist? How certain that residential layout influence people to interact?

Anuar, T. et.al. (2011) suggested that the original pattern of housing must be used as a reference to Muslim residential design today. He believes the Western-based interpretation of human habitation is derived from the human-centred paradigm that only feature functional and aesthetic aspects must be disregarded. The housing design became too simple and senseless without soul as a result of neglecting the spiritual elements in the design. Spiritual aspects should dominate the Islamic residential design in a way that;

a. The house and its immediate environment should be a place to foster the growth of a family, developing a true Muslim personality for oneself, the children and other family members.

b. The spaces are peaceful to the heart, soul and offer sense of repose

c. The space that is isolated from the outside world

d. The spaces to exercise socializing based on the tenets of Islam.

e. Space to draw closer to God in order to achieve the highest level of faith.

f. The use of the latest technologies and techniques appropriate to the current situation as long as it can help to achieve the level of comfort, thus improving the relationship with God.

Therefore, in the process of developing a Muslim family, which is true to the context of the Islamic religion, Anuar, T. et.al. (2011) reiterated that a proper housing design that takes into account the principles defined above must be adhered to.

\section{ISLAMIC VALUES IN THE MALAY COMMUNITY}

The term 'value' is a presumption that sets a selection pattern of the shapes, tools and goals of the action. The value system in the Malay community, comprises of three dominant aspects of relationships, i.e., between Man and God, Man to Man and Man to the Environment. In other words, it is the guiding principle that shaped human behaviour. Values also influenced the way of thinking, how we behave, human relationships and the implementation of our daily tasks (Abdul Karim, J. and Rezo, K., 2012).

What is meant by 'Islamic values' in the design of a house and its surroundings? Yusoff et.al. (2004) lists several Islamic values found in traditional Malay house design that includes the need to separate between male and female occupants who are non"ajnabi". In the context of the design of the house, it is understood as an element of privacy. In addition, the concept of privacy in Islam can also be observed in the account 
Noor Aimran Samsudin \& Syed Zainol Abidin Idid

Influences of Housing Settings and Designs in Fulfilling the Malay Residents' Social Cultures

of separating the sleeping areas between boys and girls since the early age of seven years; separating gathering place for male and female guests; evade gazing directly into a house and avoid entering someone's home without permission.

Islam also emphasizes on the concept of neighbourhood as a fundamental aspects of a society. According to the definition of Fiqh, neighbours are those who live near a person's house within a span of 40 houses to the left, right, front and the rear. Islam also encourages a person to know a potential neighbour who will live near his home so that it will initiate a sense of togetherness (sense of belonging) and harmony. In the open housing market today is most unlikely that a person is able to choose their neighbours. By comparison, people in the kampongs know more of their neighbours than those who are living in the designated housing areas in the city. The attitude of helping and taking care of one another in a neighbourhood is the virtual attribute of every inhabitant in the kampong. Indirectly, it becomes a form of social surveillance that can provide harmonious relationship between neighbours.

\section{HOUSE, KAMPONG AND THE MALAY SOCIETY}

The house is a place of residence or place of human habitation built with pillars, walls and roof. While in terms of functionality, the house has a different function with other buildings such as mosques, sheds and huts. According to Yaakub, I. (1996), there are some similarities in the architectural features of traditional houses in the Malay Archipelago whether in Thailand and Indo-China, namely:

a. Constructed on pillars and raised floors above the ground

b. With long articulated roofs, high and sloped and complete with facia board

c. Multilevel roofs, glazed

d. With "serambi" or "selasar"

e. Pillars with stones or wooden based

f. The construction using "pasak" (wooden pegs) without using iron nails

However, a house cannot be seen just as a physical entity that serves as a shelter alone. This is because each unit complements each other in an environment that is known as a place to stay. The traditional Malay community inhabits the settlement known as "kampung", kampong or village. Traditionally, the natural environment and the socialcultural aspects of their neighbours influence a settlement. The traditional kampong consists of several traditional houses and is surrounded by a scenic natural environment including forests, rivers, and beaches. According to Mohd Yusof, H. (2011), the ideas and aspirations to build a residential community begins from site selection of a suitable home to live in. Subsequently, the increase in population from time to time, established a range of houses in a group known as the kampong.

The kampong is home to the Malay community and each cluster of houses is usually inhabited by a family (Zul Azri, A.Z. et.al. 2010). The cluster of houses in the kampong exists because the community is concerned with aspects of family relationships. Typically, a parcel of land containing several houses occupied by family members either siblings or relatives. They prefer to stay close to each other to facilitate in getting help or assistance when needed. This phenomenon can be observed through the practice of mutual help among family members and the community. 
Indirectly, the kampong is also a 'housing scheme' as seen today. Significant differences between the characteristics of the kampong and the modern housing schemes are that the traditional settlement is not professionally designed, with any development plan or specific guidelines. However, Malay kampong serves as a settlement in the Malay community. To understand the impact of the kampongs on residents, some layout elements or the design settings have to be investigated. The followings are the elements of 'design' for the living environment in the traditional Malay kampongs:

\section{The Concept of the Border}

In the kampong, there is no clear physical boundary. Homes often do not have a fence or walls to demarcate their area. The composition of the houses in the kampong is organic and free. Nonetheless, as a centralized settlement pattern, linear and scatter can be observed, these patterns are influenced by natural elements. In addition to that, the spaces that exist between the houses are communal spaces. The space is used collectively with the neighbours for social functions such as feasts and children's play area. Often the natural elements such as fruit trees mark the boundaries of houses in an informal way while the drains and streams are referred to as the border between settlements or kampongs. Collectively, the 'openness' of the settlement pattern is believed to promote the interrelationship between communities of the interwoven neighbourhoods.

The concept of openness or neighbourhood without fences has been introduced in a two-storey linked housing area in Putrajaya. According to the study by Roslan, T. (2011), the application of the concept housing without borders or fences on the linkedhouses is believed to promote neighbour relations. The concept, however, needs to be carefully reviewed in the context of its implementation to the current community. Mohamad Tajuddin, M.R. (2009) in an article published by The Star claimed that the concept is not conducive in urban residential areas due to the lifestyle of the urban community is different from that of those in the kampongs. Mohamad Tajuddin further said "it sounded good on paper: a modern housing estate with no divisive fences, but it does not quite work in the real, Malaysian world." Security and privacy issues are some major defects that have been identified.

\section{Housing Settings}

Based on the study by Choo (1982), there are two types of housing settings (layouts) in the kampongs of Peninsular Malaysia i.e. the clusters and linear forms. The pattern of clustered kampongs can be found in the area of flatland, estuary and urban areas. The linear patterns are found along the rivers, coastal areas and major road networks. Syed Zainol Abidin, I. and Shazramimin,S. (2011) found that the clustered form of housing settings in the kampong encourages the residents to conduct activities together, increase the level of public surveillance and promote the spirit of togetherness (sense of belonging).

\section{Suitable Distance between Housing}

An appropriate distance between each house is required when designing the housing units in a settlement. If the houses are too close to one another, they can compromise the feeling of privacy and caused the feeling of discomfort. Violation of privacy can occur 
Noor Aimran Samsudin \& Syed Zainol Abidin Idid

Influences of Housing Settings and Designs in Fulfilling the Malay Residents' Social Cultures

in respect to view. Islam also prohibits the act of spying or snooping into other people's homes. In a hadith which means:

"Anyone who peeks or looks inside the home of a people without their consent is unlawful for them, then surely for the owner the right for the prier's eyes to be gouged" Source: Translate from e-hadith (2015)

For example the lane behind the house in a linked house type, invites invasion of privacy to homeowners (Mohamad Tajuddin, M.R., 2007). Setbacks in the alley behind a linked house unit must be about 4 to 7 metres from the wall separates the rows behind the houses allowing a certain level of privacy (See Figure 1):

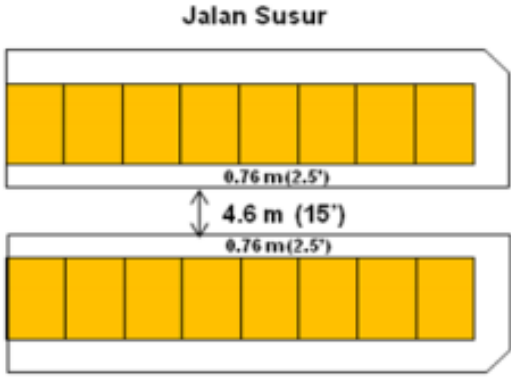

Typical back lane design

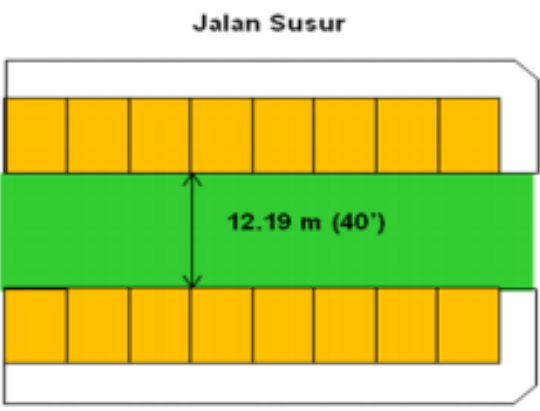

Alternative back lane design

Figure 1: Position housing units that are too close may cause an invasion of privacy to residents (Right). The house window at the back was built in parallel with a row of other houses which may increase uncomfortable feelings among residents. One of the proposed new designs of back lanes (Left) Source: Original illustration from FDTCP, 2012)

The main function of a back alley is for the purpose of; emergency lane, fire prevention, service routes that include phone lines, sewerage, drainage, garbage collection and sewerage maintenance (FDTCP, 2012). However, it is found that the back lane also contributes to the issue of wastage of land, security problems, low environmental quality and abuse of usage. In the Malay kampong, houses were elevated and built on stilts increasing the higher sense of privacy and the occupants are at a vantage level above ground or the street level, thus avoiding direct visual intrusion by others (See Figure 2): 


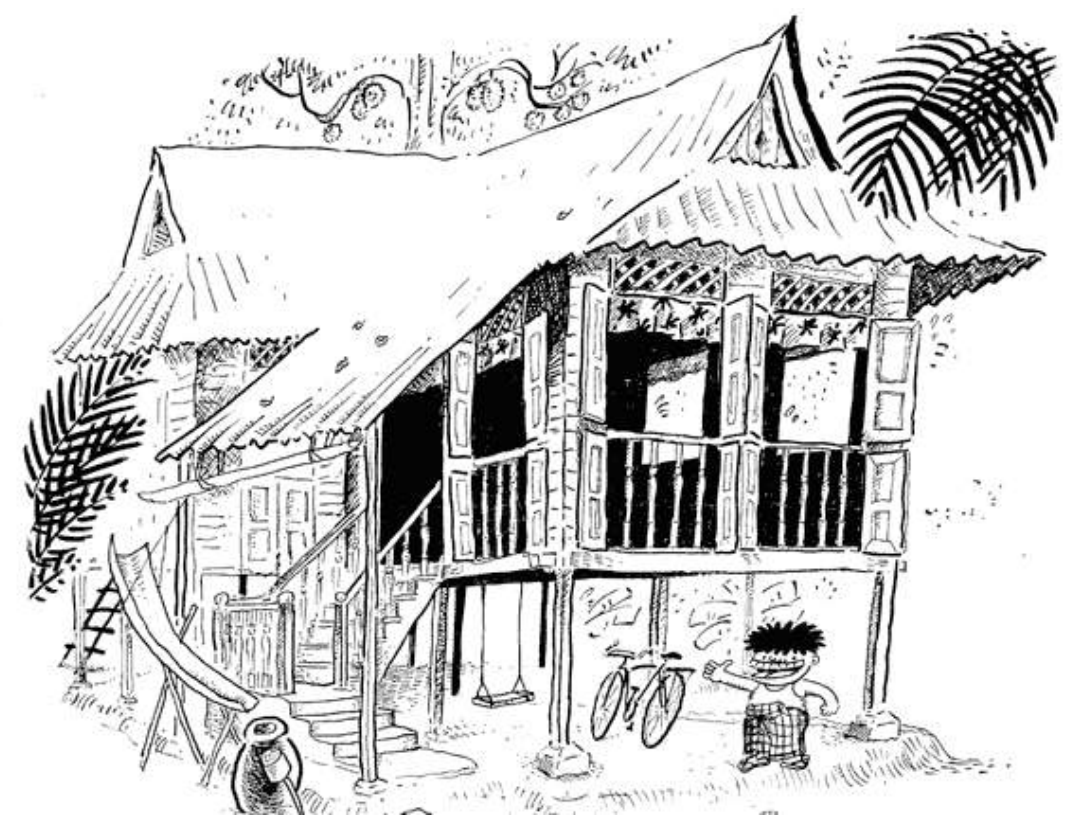

Figure 2: The illustration shown is the typical traditional Malay houses in kampongs built on stilts

Source: Original illustration by Lat in the Kampung Boy

In addition, the traditional Malay houses are built separately, detached and situated in a suitable distance from each other. But the concept is no longer an option for developers, especially the urban areas. High property values and limited spaces in urban areas tend to cause developers to build high-density residential than detached houses (Refer to Figure 3):

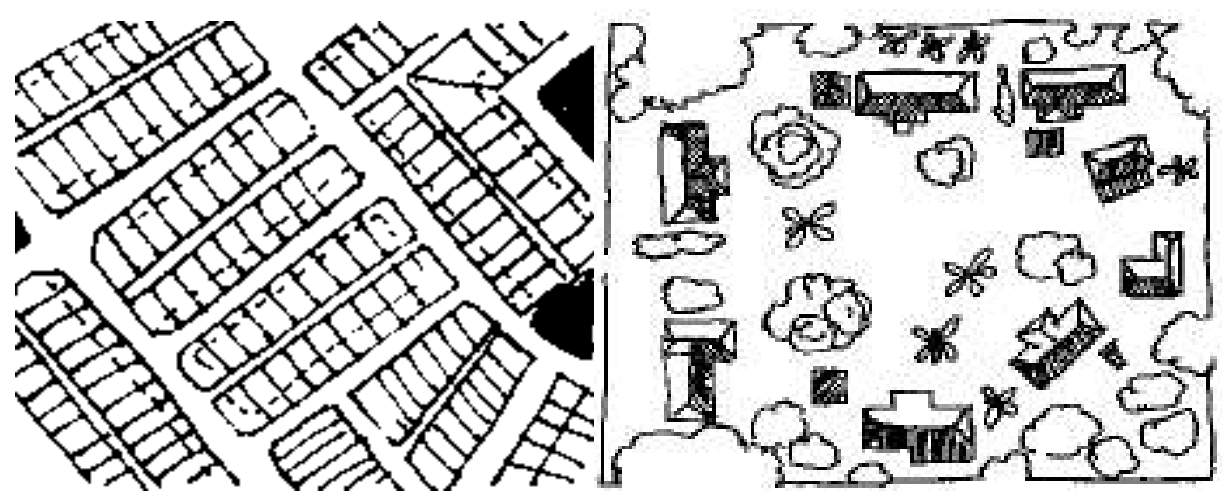

Figure 3: The illustrations show the difference of density and houses arrangement in urban housing and the traditional kampongs. The rigid gridiron typical mass urban housing in Malaysia (left picture) and an organic settlement in rural area (right picture). Source: Original illustration by author 
Noor Aimran Samsudin \& Syed Zainol Abidin Idid

Influences of Housing Settings and Designs in Fulfilling the Malay Residents' Social Cultures

\section{LINKED HOUSES-A STUDY OF EXISTING ENVIRONMENT SETTINGS}

In Malaysia, there area two main types of landed residential (buildings on land) and strata (multi levelled buildings). The type of houses in the landed residential can be classified to be detached houses, semi-detached houses, linked-houses, clustered houses, townhouses and shop houses. While the strata type consists of flats and apartments. This paper only discusses the conflict affected in the linked-house type in meeting the demands and values of Islam of their residents. Linked-house type is one of the most prominent homes in the current real estate market and is known as the home for low and medium income earners. The main feature of the linked houses is the way they are designed in a linear formation sometimes over a gentle hill slope and are in some cases terraced. This housing concept is also known as 'terraced houses' in this country. Because of this arrangement, it is difficult to arrange the house in a variety of layout patterns. Gridiron compositions have always been a top choice of developers in the development of terraced housing in order to save costs. Since the concept of 'terraced houses' was introduced in Malaysia in 1960's to1970's, various types and variety of home designs were introduced. There are also efforts made to introduce elements of traditional design of residential areas. But Abdul Hadi Harman, S. and Julaihi, W. (2010), found that without understanding the function, ideal, and cultural norms of a design, element is only used to present the surface expression of the building only.

\section{DISCUSSION}

This paper proposes to examine the issues concerning the implementation of Islamic values among the Malay community in the residence from two main perspectives, namely at the micro level, i.e. the context of a house of and of macro levels in the context of the environment that surrounds the housing units. At the micro level, the issue of privacy will be focussed. While on a macro level, the neighbourhood concept and social interactions are being focussed.

\section{Separation of Space by Gender (Concept of Privacy)}

Modern housing units for example, are not able to expand or contrive according to the needs and desires of the owner. The case is very different from the traditional Malay houses, which are so easily expanded or contrived or even removed in accordance with the interests, and needs of the owners and surrounding community (Nangkula, U. and Kosman, K. 2009). Isolation of beds, gender segregation between 'ajnabi' and non'ajnabi' are the aspects that are taken into account by the purchaser. Linked-houses on the market usually have more than three rooms to satisfy these needs. One room for the parents and each other rooms for boys and girls. However the rooms are generally too small that the occupants do not feel comfortable using them. Islam prescribes that boys and girls are separated when they reached 10 years of age, so that to avoid problems related to privacy and especially those that may lead to incest. In the past, in the traditional Malay houses, the room is used only by parents, while males will sleep on the 'serambi' and the females will use either the other available room or a special area within the 'rumah $i b u$ ' bounded by curtains or any kind of fabric separators. In the hadith of Abu Dawud, Prophet Muhammad said: 
"Teach your children to pray when they are seven years old, and when they are ten years old, beat them (if they refuse to pray) and part of their bed (boys and girls)."'Source: Translate from e-hadith (2015)

The question here is whether the size of the bedrooms built today meets the minimum space requirements of the dwellers? What about those who have large family members - how can they adapt to this kind of home design? The structure of the linkedhouses designed lengthwise backwards does not allow the increase in the number of rooms unless; the house is a corner lot. Owners of intermediate houses (in the middle of a row) of the linked-houses will only be able to increase the number of bedrooms at the expense of the setback spaces in front or at the back of the houses prescribed by the guidelines, only if they are given permission to do so. In most circumstances, these permissions are impossible to obtain. With a larger compound, the traditional Malay house features a more dynamic aspect as they are designed in modules. Certain parts of the house can be modified in accordance to the needs of the home owners.

\section{The Neighbourhood Concept in the Malay community}

A neighbourly relation is very important in a community, especially for the Malay community. Since time immemorial, the community has been living in groups close to each other and can be seen from the layout of the house in the kampongs. The houses are arranged in groups according to the family unit. Two or more members of the family consisting of siblings or close relatives often occupy one lot. Indirectly, neighbourly relations in the kampong are better than in urban areas because it is established on the basis of family ties. However, Mohd Yusof, H. (2011) found that the family relationship alone is not sufficient to ensure the well-being or rather good neighbourly relations, which often considered as a determinant of the level of well-being of a community. Islam requires its followers to care for the rights of their neighbours and to take care of their neighbours. It is based on Ibn. Umar and Aisha both said, Rasulullah (P.B.U.H) said which mean:

"Always Gabriel counsels upon me about to be kind with neighbours, so that I think he (neighbour) is eligible to inherit my assets" (Hadith of Bukhari and Muslim) Source: Translate from e-hadith (2015)

In another narration, Abu Dhar (R.A) also reported:

"Indeed, my beloved (Prophet Muhammad) has told me, when you cook meat, add more water, then take a look at your neighbours and family members and give a part of it in a good way." (Hadith of Muslim) Source: Translate from e-hadith (2015)

Besides that ALLAH says in Surah An-Nisaa ', verse 39, which says:

"And that you worship Allah and do not associate anything with Him with anything whatsoever, and do good to parents, kinsfolk, orphans, the poor, neighbours who are near or even distant, colleagues, travellers who are 
Noor Aimran Samsudin \& Syed Zainol Abidin Idid

Influences of Housing Settings and Designs in Fulfilling the Malay Residents' Social Cultures

displaced and slaves those whom you possess; verily ALLAH loveth not the arrogant, haughty and proud of himself"

Generally there are three types of neighbours who are distinguished from the rights of a person as a neighbour (Refer to Table 1 below).

Table 1: Summary of Neighbours type from Islamic Perspective

\begin{tabular}{ll}
\hline \multicolumn{1}{c}{ Types of Neighbour } & \multicolumn{1}{c}{ Types of Rights } \\
\hline Muslim neighbour + blood ties & Neighbouring rights, Muslims \& relatives \\
Muslim neighbour + without blood ties & Neighbouring rights and Muslims \\
Non-Muslim neighbours & Neighbouring rights \\
\hline Source: Author &
\end{tabular}

According to Muslim (R.A.) narrated from Abdullah bin Amr (R.A.) that Rasulullah (P.B.U.H) said:

"Neighbours are three types: There are among them who has three rights, some have two rights and some have only one right. The neighbour who has three rights is a Muslim neighbour who has a family relationship, which to this neighbour, the right to be neighbours, the right as a fellow Muslims, and the rights of kinship. The neighbour who has two rights is the Muslim neighbours. To this neighbour the rights of a fellow Muslim and the right to be the neighbour. While neighbours who have one right are the neighbour who is a disbeliever who has only the right to be a neighbour" (Hadith of Muslim) Source: Translate from e-hadith (2015)

The question that arises is whether the present design of housing encourages residents to interact with each other and improve neighbourhood relations? An interaction may occur when there is a similarity between the individual and a mutual purpose. Muslim quoted Ali bin Abi Talib (R.A.) means that the Prophet said:

"Choose your neighbours before (building) the house, and (choose) friends before travelling and (provide) the sustenance before death." Source: Translate from e-hadith (2015)

Today, home owners do not have the opportunity to choose their neighbours with a home purchase in the open market system. But that is no reason for someone not taking care of the relationship between neighbours and keeps their rights. A more ideal housing layout design is believed to improve the neighbourhood relationship of a community. For example, clustering and ideal housing layout in the kampong encourages residents to interact with each other. Syed Zainol Abidin, I. and Shazramimin, S. (2011), suggest that small changes to the design of existing housing layout and the promotion of cluster houses like those in the 'traditional kampong' will foster social interaction in the neighbourhood. 


\section{CONCLUSION}

Malay communities are rich with their customs, culture and values guided by the Islamic principle. However, the design of modern housing in urban areas today is often found to ignore the socio-cultural needs of the residents, whether at the micro (a single unit house) and macro (the neighbourhood) level. This paper suggests that the design and concept of housing in this country should be reviewed. In order to promote an ideal living environment for the Malay-Muslim community, lessons can be learned from the traditional settlements such as the Malay kampong. This is because the mass housing concept that is being practiced has been copied out from the experience of Western countries which does not suit the local social-cultural background. A house unit and the whole neighbourhood should be a place where the social development occurs and shape. Children, as for example, are brought up in certain settings where they are influenced by the design and physical housing configuration. They are embedded with good values while growing up and will become part of society in the future. A good living environment can create a good society. This study suggested that the traditional kampongs concept should be explored in detail and used as a basic guide in providing the better residential area. The kampongs sphere should be translated into the new modern housing area that does not only stress on the local cultural identity, but also taking into account the needs and aspirations of the inhabitants of the Malay-Muslim community. This is because, the traditional Malay kampongs that have existed, developed and tested through time has found to be able to build a society that is often described as always taking care of each other, helping each other and interacting in harmony within the living environment. Hence, it is hoped that future national housing design will take into account the social aspects, the formation of individual personality, values and beliefs by providing a more ideal place to live, conducive, high quality and uphold the noble values of Islam.

\section{REFERENCES}

Zul Azri, A.Z., Dilshan, R.O and Syed Zainol Abidin, I. (2010) The Islamic Malay Traditional Towns, Learning Through The Attributes Special Emphasis On Johor Bahru, Malaysia. In: International Conference for Urban \& Architectural Heritage in Islamic Countries. Riyadh.

Abdul Hadi Harman, S. and Julaihi, W. (2010). Konsepsualisasi Ruang dan Habitat Tradisional Melayu. Sari-International Journal of the Malay World and Civilisation, 28(1), pp.117-187.

Abdul Karim, J. and Rezo, K. (2012). Pembentukan Skala Pengukuran Nilai Melayu: Satu Kajian Perintis. Journal of Southeast Asia Social Sciences and Humanities, [online] 82(1), pp.113-123. Available at: http://ejournal.ukm.my/akademika/article/view/845/788 [Accessed 13 Oct. 2015].

Anuar, T., Mohd Dani, M. and Muhammad Suhaimi, M. (2011). Prinsip Islam di Dalam Ruang Kediaman Muslim. [online] Versys.uitm.edu.my. Available at: http://versys.uitm.edu.my/prisma/view/viewPdf.php?pid=57747 [Accessed 6 Apr. 2015].

Choo, T. (1982). The Application of Traditional Design to Contemporary Housing in Malaysia. Master. Massachusetts Institute of Technology.

Department of Statistics (2010). Preliminary Count Report Population and Housing Census of Malaysia. Putrajaya: Department of Statistics, p.20. 
Noor Aimran Samsudin \& Syed Zainol Abidin Idid

Influences of Housing Settings and Designs in Fulfilling the Malay Residents' Social Cultures

Federal Department of Town and Country Planning Peninsular Malaysia (JPBD), Ministry of Housing and Local Government (2012). Back Lane Planning Guidelines 025 (Draft2012).

Islam.gov.my, (2015). Senarai Hadith | Department of Islamic Development Malaysia. [online] Available at: http://www.islam.gov.my/en/e-hadith [Accessed 16 Jun. 2015].

Jeannot Abdul, K. and Khairul Anuar, R. (2012). Pembentukan Skala Pengukuran Nilai Melayu: Satu Kajian Perintis. Akademika, 82(1), pp.113-123.

Mohamad Tajuddin, M.R. (2007). Housing crisis. Skudai, Johor Darul Ta'zim: Penerbit Universiti Teknologi Malaysia.

Mohamad Tajuddin, M.R. (2009). Archives|The Star Online. [online] Thestar.com.my. Available at:http://www.thestar.com.my/story.aspx/?file=\%2f2009\%2f2\%2f15\%2flifefocu s\%2f3239168\&sec=lifefocus [Accessed 13 Apr. 2014].

Mohd Yusof, H. (2011). Hubungan Kejiranan dalam Membentuk Kesejahteraan Hidup Masyarakat 'Kampung Bandar': Kes Kampung Berjaya dan Kampung Mempelam, Alor Setar, Malaysia. Malaysian Journal of Society and Space, 7(3), pp.36-44.

Nangkula, U. and Kosman, K. (2009). Rumah yang Berkembang: Pengajaran daripada Keanjalan Matematik.. [online] Kesturi.net. Available at: http://www.kesturi.net/?p=929 [Accessed 16 Jun. 2015].

National Housing Department, (2011). National Housing Policy. Kuala Lumpur: Ministry of Housing and Local Government.

Prpm.dbp.gov.my (2015). Pusat Rujukan Persuratan Melayu @ DBP. [online] Available at: http://prpm.dbp.gov.my/Search.aspx?k=rumah [Accessed 13 Oct. 2015].

Roslan, T. (2011). Post-Occupancy Evaluation on the selected Government's Double Storey Terrace Housing Units in Putrajaya, Malaysia. Asia Culture and History. Vol. 3 (1). pp.125-137.

Syed Zainol Abidin, I. and Shazarimin, S. (2011). Traditional Values in Modern Living, a dilemma of choice?. [online] Academia.edu. Available at: https://www.academia.edu/1325433/Traditional_Values_in_Modern_Living_a_d ilemma_of_choice [Accessed 10 May 2015].

Yaakub, I. (1996). Rumah tradisional Negeri Sembilan. Shah Alam: Fajar Bakti. 